DOI: $10.14451 / 1.186 .111$

\title{
СПОСОБЫ ДОБЫЧИ ТРУДНОИЗВЛЕКАЕМЫХ ЗАПАСОВ НЕФТИ
}

\author{
(c) 2020 Серков М. A. \\ магистрант \\ Санкт-Петербургский государственный экономический университет, Россия, Санкт-Петербург \\ E-mail: Maximserkov1@gmail.com
}

В данной статье рассматривается деятельность нефтедобывающих компаний России и доказывается наличие потенциала увеличения нефтедобычи благодаря освоению труднодоступных месторождений, сконцентрированным в определенных регионах страны.

Ключевые слова: добыча нефти, трудноизвлекаемые запасы, государственно-частное партнерство, труднодоступные месторождения, иностранные нефтяные компании

В следствие ежегодного роста мировой экономики растёт потребность государств в углеводородах как источнике энергии. На данный момент доля израсходованных запасов легкодоступных углеводородов составляет около $66 \%$. Также существуют разведанные запасы нефти, залегающие в труднодоступных источниках, которые на данный момент практически не израсходованы. Нефть из таких месторождений принято называть трудноизвлекаемой, так как особенности геологических пластов, в которых залегают запасы данной нефти, мешают осуществлению рентабельной нефтедобычи, основанной на достигнутом в настоящий момент уровне применяемых технологий. К трудноизвлекаемым запасам нефти относятся:

a) запасы в низкопроницаемых породах;

б) подгазовые залежи;

в) остаточные запасы в разработанных месторождениях;

г) высоковязкая нефть;

д) нетрадиционные запасы в месторождениях в удаленных и труднодоступных районах.

По оценкам специалистов ПАО «Газпромнефть», на территории Российской Федерации доля трудноизвлекаемых углеводородов составляет до $60 \%$ от совокупного количества всех запасов.

При установившихся на мировом рынке нефти ценах в диапазоне 30-40 долларов за баррель, из-за устаревших технологий нефтедобывающие компании не смогут сохранить достаточную рентабельность добычи из труднодоступных месторождений. Необходимо совершенствовать способы добычи.

Необходимость освоения трудноизвлекаемых месторождений для добычи нефти на тер- ритории Российской Федерации существенно возросла. Рост данной необходимости обусловлен двумя основными причинами:

1) установившиеся низкие цены на нефть на мировых торговых площадках;

2) истощение запасов в традиционных источниках добычи нефти в России.

Из-за ряда факторов Россия не способна в короткие сроки сократить значительное технологическое отставание от стран США и Европейского союза технологиях добычи углеводородов из труднодоступных месторождений. Следовательно, требуется увеличение инвестиций в разработку и совершенствование существующих инженерных технологий со стороны как нефтяных компаний, так и органов государственной власти, а также заимствование опыта иностранных компаний при освоении труднодоступных месторождений, что обеспечит существенный прирост рентабельности добычи нефти в стране в долгосрочной перспективе.

Усложняет ситуацию «сланцевая революция», начавшаяся в США в 2013-2014 годах, напрямую затрагивающая интересы российских нефтедобытчиков, падение доходов которых негативно влияет на доходы бюджета Российской Федерации, существенная часть которого зависит от поступления налогов с продажи сырья.

Зарубежные специалисты в области нефтедобычи прогнозируют изменения в структуре добываемой в мире нефти к середине 30-х годов XXI века, в результате которых доля нефти, извлекаемой из низкопроницаемых пород, составит около 7\%, а на биотопливо будет приходиться до 4\%. При этом до 30\% таких месторождений будет разрабатываться за территорией США.

Российские нефтедобытчики в настоящий 
момент принимают меры по освоению месторождений с трудноизвлекаемыми запасами нефти. Отдельно следует отметить следующие виды осваемых углеводородов:

а) сверхтяжелая нефть;

б) нефть в низкопроницаемых коллектоpax;

в) битумная нефть.

Отдельного рассмотрения требует сложившаяся ситуация на рынке сланцевой нефти. Сланцевая нефть добывается в результате разработки труднодоступных глубокозалегающих месторождений сланцевых пластов. Такие месторождения залегают значительно глубже, чем пласты, из которых добывается традиционная нефть, что приводит к увеличению себестоимости добычи сланцевой нефти. По подсчётам финансовых специалистов ведущих мировых нефтяных компаний, 1 тонная сланца, обогащённого нефтью, в среднем позволяет получить 1 баррель нефти. В денежном эквиваленте, для нефтедобытчиков США с учётом налоговой нагрузки, цена безубыточности составляет 60 долларов за баррель (при текущих мировых ценах в 30-40 долларов за баррель).

Россия располагает значительными запасами сланцевой нефти. В месторождениях западной Сибири они оцениваются в 140 млрд. баррелей. При технологиях, которыми обладают российские нефтяные компании, извлекаемые запасы сланцевой нефти составляют около 70 млрд. баррелей. На основании этих цифр можно сделать вывод об имеющемся у России потенциале стать крупным добытчиком сланцевой нефти. Для реализации данного потенциала необходимо внедрение инновационных методов геологического изучения и технологий извлечения нефти из сланцевых залежей, а также современные способы нефтепереработки и логистики.

Такими технологиями в достаточной степени обладают западные нефтяные компании. Доступ российских нефтедобытчиков к данным технологиям в настоящий момент сильно ограничен из-за введённых в 2014 году антироссийских санкций странами ЕС и США.

Одной из мер, которая позволит оказать поддержку российским нефтяникам в условиях экономических и технологических санкций ЕС и США, может стать законодательное введение налоговых послаблений для нефтяных компаний, добывающих сырьё из трудноизвлекаемых месторождений углеводородов. Такая мера приведёт к высвобождению части собственных средств предприятий для инвестиций в программы по добыче трудноизвлекаемых запасов нефти.

На данный момент в Налоговом Кодексе Российской Федерации Налоговый Кодекс РФ отдельно выделены территории, на которых расположены месторождения с трудноизвлекаемыми запасами нефти. На добычу нефти на данных территориях применяются льготы по налогу на добычу полезных ископаемых. К этим территориям Налоговый Кодекс РФ относит:

1) участки недр, расположенные в Якутии, Иркутской области, Красноярском крае, ЯмалоНенецком АО, полуострове Ямал;

2) участки недр, расположенные севернее 65 градусов северной широты ЯНАО;

3) залежи нефти севернее Северного полярного круга во внутренних морских водах и территориальном море России;

4) запасы нефти на континентальном шельфе России;

5) залежи нефти на участках недр в Азовском, Каспийском, Черном и Охотском морях;

6) залежи нефти Баженовской, Абалакской, Хадумской, Доманиковской и Тюменской свит.

Месторождения на перечисленных территориях нефтедобывающие компании России совместно разрабатывали с коллегами из европейских государств. В частности, «Газпром» планировал разработку Южно-Киринского месторождения на шельфе Сахалина в партнёрстве с британско-нидерландской компанией «Shell», но в результате наложенных на месторождение точечных санкций США и ЕС переговоры были приостановлены.

В настоящий момент, ПАО «Газпром нефть» ведет переговоры по привлечению «Shell» в проект освоения Аяшского участка на Сахалинском шельфе, где было открыто месторождение Нептун с запасами нефти в 415 млн. тонн. Потенциальному сотрудничеству с западными коллегами снова могут помешать западные санкции, хотя на данный момент совместное освоение Аяшского участка ими не запрещено: шельф Сахалина не является арктическим, а глубина моря в пределах площади не превышает 150 метров.

По словам первого заместителя председателя правления ПАО «Газпром-нефть» Вадима Яковлева, «потенциальные риски повторения судьбы Южно-Киринского месторождения, также расположенного на Сахалинском шельфе, су- 
ществуют. Его «Газпром» хотел разрабатывать совместно с «Shell», но в результате наложенных на месторождение точечных санкций США переговоры были остановлены» [7].

Несмотря на предоставление налоговых льгот для компаний, разрабатывающих труднодоступные месторождения нефти на территории Российской Федерации, данного преимущества недостаточно для рентабельного освоения запасов труднодоступной нефти. Необходимо использование иностранного опыта. Требуется создание благоприятных условий для западных нефтедобывающих компаний, желающих принять участие в освоении труднодоступных месторождений нефти на территории Российской Федерации. Также стоит искать возможности обхода антироссийских санкций при таком со- трудничестве. Помимо данных мер, стоит законодательным образом закрепить обязанность крупных российских нефтяных компаний некоторую часть прибыли инвестировать в развитие научных разработок в нефтегазовой сфере, чтобы в перспективе сократить технологическое отставание.

Инвестиции в добычу нефти из месторождений с трудноизвлекаемыми запасами на территории Российской Федерации приводят к мультипликативному эффекту в связанных сферах хозяйственной деятельности. Особую важность представляют принимаемые Правительством РФ меры по координации, контролю и стимуляции производства в области добычи полезных ископаемых из труднодоступных месторождений.

\section{Библиографический список}

1. Шарф И.В. Анализ структуры финансирования геологоразведочных работ в регионах Восточной Сибири // Нефтегазовое дело. - 2014. - № 1.- С. 196-202.

2. Ильина Г.Ф., Ильин Н. Н. Текущая ситуация в сфере геологоразведочных работ на территории Томской области // Молодой ученый. - 2014. - № 13.- С. 104-107.

3. Bajus M. Shale gas and tight oil, unconventional fossil fuels // Petroleum \& Coal.-2014.-56(3).- C. 206-221.

4. Bryden K., Federspie M., Habib E. T., Schiller R. Processing Tight Oils in FCC: Issues, Opportunities and Flexible Catalytic Solutions// Grace Catalysts Technologies Catalagram. - 2014. - № 114. - Pp. 3-23.

5. Левинбук М.И., Котов В. Н. Изменение структуры потребления основных энергоносителей в США - один из вызовов энергетической безопасности России // Мир нефтепродуктов. - 2013. - № 9. - С. 3-14.

6. Байков Н.M., Байкова Е.Н. Перспективы разработки месторождений сланцевой нефти // Нефтяное хозяйство.- 2013. - № 5.- С. 120-123.

7. «Газпром нефть» зовет Shell на шельф - [Электронный ресурс]. - Режим доступа: https://www.kommersant. $\mathrm{ru} / \mathrm{doc} / 3798073$ 